\title{
ТВЕРДЕ ТІЛО
}

\section{ЕЛЕКТРОННА СТРУКТУРА ТВЕРДИХ РОЗЧИНІВ GaInN 3 ДОМІШКАМИ ХРОМУ І ВОДНЮ}

\author{
С.В. СИРОТЮК, В.М. ШВЕД
}

Національний університет "Львівська політехніка", кафедра напівпровідникової електроніки

УДК 537.311.322 (Вул. С. Бандери, 12, Лъвів 79000; e-mail: svsnpe@ yahoo. com)

Електронні та магнітні властивості твердих розчинів $\mathrm{GaInN} 3$ домішками хрому і водню було розраховано за методом функції Гріна. Отримані парціальні та повні спін-поляризовані щільності електронних станів вказують на докорінну перебудову електронної структури кристала, спричинену атомами заміщення Cr та міжвузловими домішковими атомами водню. Зміни пов'язані з появою у забороненій зоні вузьких гібридизованих зон $s-, p$ - і $d$-симетрії, відсутніх у твердих розчинах GaInN.

\section{1. Вступ}

Розбавлені магнітні напівпровідники привертають увагу дослідників, оскільки вони можуть використовуватися в спінтроніці, інтегрованих оптоелектронних пристроях і квантових наноструктурах [1]. Сплави нітридів, що містять індій, є важливою складовою оптико-електронних приладів: наприклад, активний шар короткохвильових світловипромінюючих діодів і лазерних діодів, зазвичай, складається $3 \operatorname{In}_{x} \mathrm{Ga}_{1-x} \mathrm{~N}$ [2]. Енергії формування дефектів у кристалах AlN i $\mathrm{GaN}$, зв'язані з легуванням донорними (O, Si, Ge) та акцепторними ( $\mathrm{Li}, \mathrm{Be}, \mathrm{Mg}, \mathrm{Ca}, \mathrm{Zn}, \mathrm{Cd}$ ) домішками, були розраховані у наближенні теорії функціонала електронної густини (DFT) за допомогою зберігаючих норму атомних апріорних псевдопотенціалів [3]. Водень, який у нітридах виникає в процесі вирощування за MOCVD- та HVPE-технологіями, виявляє значний вплив на їхні властивості [3]. Збільшення вмісту In у сплаві, в принципі, дає можливість розширення діапазону випромінювання світла від ультрафіолетового до червоного. У кристалі $\mathrm{GaN}$ з домішкою $\mathrm{Cr}$ (3) було виявлено експериментально найбільше значення магнітного моменту [4]. Однак тверді розчини
InGaN $з$ домішками $3 d$-елементів на сьогодні $є$ мало вивченими. Знання природи точкових дефектів у сплавах InGaN є важливим першим кроком до розуміння їхньої ролі у фізичних процесах. Зміни електронної структури кристала GaInN під впливом сумісної дії домішок $\mathrm{Cr}$ та Н мають як теоретичне, так і практичне значення. Тому мета даної роботи така: 1) розрахунок парціальних і повних щільностей електронних станів (DOS) у твердих розчинах GaInN; 2) обчислення магнітних моментів всіх атомів у комірці; 3) розрахунок повних енергій зв'язку твердих розчинів; 4) аналіз змін електронної структури кристала, зумовлених присутністю домішкових атомів $\mathrm{Cr}$ та Н. У розділі 2 коротко описано метод розрахунку. Розділ 3 присвячено аналізу отриманих результатів. У розділі 4 наведено висновки.

\section{2. Розрахунок}

Обчислення атомних і термодинамічних властивостей напівпровідників з дефектами проводяться за допомогою атомних апріорних псевдопотенціалів [3, 5], однак застосування цього методу до систем 3 домішками $d$ - та $f$-елементів на сьогодні рідкісні. Тому ми виконали розрахунок електронної структури твердих розчинів з домішкою $d$-елемента за допомогою програми AkaiKKR [6], яка дає змогу проводити самоузгоджені розрахунки не тільки сполук з перехідними елементами, а й невпорядкованих систем [7]. Програма грунтується на розрахунку функції Гріна у кристалі [6]:

$G\left(\mathbf{r}+\mathbf{R}_{\mathbf{n}}, \mathbf{r}^{\prime}+R_{n^{\prime}} ; E\right)=-i \sqrt{E} \sum_{L} R_{l}^{n}\left(\mathbf{r}_{<;} ; E\right) \times$

ISSN 2071-0194. Укр. фіз. журн. 2012. T. 57, №10 
$\times H_{l}^{n}\left(\mathbf{r}_{>} ; E\right) \delta_{n n^{\prime}}+\sum_{L L^{\prime}} R_{L}^{n}(\mathbf{r} ; E) G_{L L^{\prime}}^{n n^{\prime}}(E) R_{L^{\prime}}^{n^{\prime}}\left(\mathbf{r}^{\prime} ; E\right)$

де $\mathbf{r}_{<}$та $\mathbf{r}_{>}$означають один з двох векторів $\mathbf{r}$ та $\mathbf{r}^{\prime}$, що має меншу або більшу довжину. Хвильові функції $R_{L}^{n}(\mathbf{r} ; E)$ та $H_{L}^{n}(\mathbf{r} ; E)$ задаються добутками радіальних власних функцій на сферичні гармоніки:

$R_{L}^{n}(\mathbf{r} ; E)=R_{L}^{n}(r ; E) Y_{L}(\mathbf{r}), H_{L}^{n}(\mathbf{r} ; E)=H_{L}^{n}(r ; E) Y_{L}(\mathbf{r})$

де $R$ - регулярний розв'язок радіального рівняння Шредінгера у центральному потенціальному полі $\nu^{n}(r)$, пропорційний сферичній функції Бесселя $j_{l}(\sqrt{E} r)$ на вузлі кристала всередині МТ-сфери, тобто за умови $r<R_{\mathrm{MT}} ; H-$ нерегулярний розв'язок, що описує розсіяну хвилю поза МТ-сферою і дорівнює сферичній функцї Ганкеля $h_{l}(\sqrt{E} r)$. Остання не існує у точці $r=0$. Функції $H$ та $R \in$ одновузловими, тоді як структурна матриця функції Гріна $G_{L L^{\prime}}^{n n^{\prime}}(E)$ описує зв'язок між розв'язками, локалізованими у різних комірках, і тому містить інформацію про розсіяння на багатьох вузлах кристала. Структурна матриця незбуреного кристала $G_{L L^{\prime}}^{(0) n n^{\prime}}(E)$ визначається з рівняння Дайсона:

$$
\begin{aligned}
& G_{L L^{\prime}}^{(0) n n^{\prime}}(E)=g_{L L^{\prime}}^{n n^{\prime}}(E)+ \\
& +\sum_{n^{\prime \prime} L^{\prime \prime}} g_{L L^{\prime \prime}}^{n n^{\prime \prime}}(E) t_{l^{\prime \prime}}^{n^{\prime \prime}}(E) G_{L^{\prime \prime} L^{\prime}}^{(0) n^{\prime \prime} n^{\prime}}(E),
\end{aligned}
$$

де $t$ - матриця $t_{l}^{n}$ на потенціалі $\nu^{n}(r)$ визначається за формулою

$t_{l}^{n}=\int_{0}^{R_{\mathrm{MT}}} d r r^{2} j_{l}(\sqrt{E} r) \nu^{n}(r) R_{L}^{n}(\mathbf{r} ; E)$,

a $g_{L L^{\prime}}^{n n^{\prime}}(E)$ - вільноелектронна функція Гріна. Функція Гріна кристала з домішкою тепер може бути отримана з модифікованого рівняння Дайсона:

$$
\begin{aligned}
& G_{L L^{\prime}}^{n n^{\prime}}(E)=G_{L L^{\prime}}^{(0) n n^{\prime}}(E)+ \\
& +\sum_{n^{\prime \prime} L^{\prime \prime}} G_{L L^{\prime \prime}}^{(0) n n^{\prime \prime}}(E) \Delta t_{l^{\prime \prime}}^{n^{\prime \prime}} G_{L^{\prime \prime} L^{\prime}}^{n^{\prime \prime} n^{\prime}}(E),
\end{aligned}
$$

де $\Delta t_{l}^{n}=t_{l}^{n}-t_{l}^{(0) n}-$ різниця між $t$-матрицями збуреного та ідеального кристалів. $\mathrm{y}$ методі KKR самоузгоджений розрахунок електронної структури кристала з домішками проводиться таким чином:

1. Розраховується стартовий потенціал кристала $V_{s}^{0}(\mathbf{r})$, де $s-$ спін електрона.

2 . Розраховується $t$-матриця $t_{L L^{\prime}}^{(0)}$ незбуреного кристала для обох орієнтацій спіна.

3. Знаходяться хвильові функції $R_{L}(\mathbf{r})$ та $H_{L}(\mathbf{r})$, за допомогою яких обчислюється $t$-матриця $t_{L L^{\prime}}$ і різниця $\Delta t_{L L^{\prime}}(E)=t_{L L^{\prime}}(E)-t_{L L^{\prime}}^{(0)}(E)$.

4. Отримується 3 рівняння (3) матриця структурних констант незбуреної системи $G_{L L^{\prime}}^{(0) n n^{\prime}}(E)$.

5. Розв'язується рівняння Дайсона (5) відносно структурних констант збуреної системи $G_{L L^{\prime}}^{n n^{\prime}}(E)$.

6. Знаходиться функція Гріна (1) з отриманих хвильових функцій $R_{L}(\mathbf{r})$ та $H_{L}(\mathbf{r})$ та матриці структурних констант $G_{L L^{\prime}}^{n n^{\prime}}(E)$.

7. Розраховується густина валентних електронів:

$\rho_{s}^{\nu}(\mathbf{r})=-\frac{1}{\pi} \operatorname{Im} \int_{E_{\min }}^{E_{\mathrm{F}}} G_{s}(\mathbf{r}, \mathbf{r} ; Z) d Z$

тут інтегрування проводиться у комплексній площині від дна валентної зони $E_{\min }$ до енергії Фермі $E_{\mathrm{F}}$.

8. Знаходяться хвильові функції глибоких електронів та їхня електронна густина.

9. 3 рівняння Пуассона шукається новий кулонів потенціал електронів у кристалі:

$V_{s}(\mathbf{r})=\int \frac{\rho_{s}\left(\mathbf{r}^{\prime}\right)}{\left|\mathbf{r}-\mathbf{r}^{\prime}\right|} d \mathbf{r}^{\prime}$,

який стає стартовим для наступної ітерації.

10. Формується повний потенціал кристала:

$V(\mathbf{r})=\sum_{n} \sum_{i} \sum_{s} \nu_{s}\left(\mathbf{r}-\boldsymbol{\tau}_{i}-\mathbf{R}_{\mathbf{n}}\right)$,

де підсумовування проводиться за координатами комірок кристала $(n)$, за атомами комірки $(i)$ й спіновими змінними $(s)$. У програмі використовується наближення МТ потенціалу, а невпорядкованість враховується у наближенні СРА, тобто когерентного потенціалу.

11. Потенціал вузла кристала визначався сумою $\nu(\mathbf{r})=\nu_{n}(\mathbf{r})+\nu_{e}(\mathbf{r})+\nu_{x c}(\mathbf{r})$, де $\nu_{n}-$ кулонів потенціал ядра атома, $\nu_{e}$ - потенціал глибоких і валентних електронів, $\nu_{x c}$ - обмінно-кореляційний потенціал усіх електронів.

12. Ітерації тривали до збіжності повної енергії кристала 3 точністю $10^{-8} \mathrm{Ry}$. Така точність досягалась приблизно за 100 кроків ітерацій. 
Обмінно-кореляційний потенціал, заснований на локальній апроксимації спінової густини в параметризації [8], було використано у наших розрахунках. Різні параметризації функціоналів обмінної та кореляційної енергії наведено у роботі [9]. Вибраний нами варіант [8] явно залежить від параметра спінової поляризації $\varsigma=(\rho \uparrow-\rho \downarrow) / \rho$, де повна густина електронів $\rho=\rho \uparrow+\rho \downarrow$, тобто є сумою густин різних орієнтацій спінів. Значення $\varsigma=0$ відповідає парамагнітному стану, а $\varsigma=1-$ феромагнітному. Для інтегрування у зоні Бріллюена використано метод МонкхорстаПака [10] на сітці $8 \times 8 \times 8$. Стала гратки твердого розчину GaInN зі структурою сфалериту розраховувалась за правилом Вегарда. Релятивістські ефекти були включені в скалярному релятивістському наближенні з урахуванням спін-орбітальної взаємодії, що дозволило знайти спінові та орбітальні магнітні моменти на всіх атомах елементарної комірки. Густина електронних станів для кожної орієнтації спіна обчислювалась за формулою

$n_{s}(E)=-\frac{1}{\pi} \operatorname{Im} \int d \mathbf{r} G_{s}(\mathbf{r}, \mathbf{r}, E)$,

де $G$ - запізніла функція Гріна [11]. Октаедричне міжвузля (Vo) локалізоване у точці 3 координатами $(1 / 2,1 / 2,1 / 2)$, а тетраедричне $(\mathrm{Vt})$ - у точці $(3 / 4 ; 3 / 4 ; 3 / 4)$.

У програмі реалізовано самоузгоджений всеелектронний підхід. Потенціал кристала формується 3 потенціалів атомних ядер та на основі хвильових функцій остовних і валентних електронів.

\section{3. Результати та їх обговорення}

У таблиці наведено електронні і магнітні властивості твердих розчинів GaInN з домішками хрому і водню, де $x$ та $y=0,03$ - концентрації атомів In та $\mathrm{Cr}$ відповідно. У таблиці введено такі позначення твердих розчинів: $\mathrm{A}=\mathrm{Ga}_{0,72} \mathrm{Cr}_{0,03} \mathrm{In}_{0,25} \mathrm{~N}, \mathrm{~B}=\mathrm{Ga}_{0,47} \mathrm{Cr}_{0,03} \mathrm{In}_{0,5} \mathrm{~N}$, $\mathrm{C}=\mathrm{Ga}_{0,22} \mathrm{Cr}_{0,03} \mathrm{In}_{0,75} \mathrm{~N}$. Позначка (Vo) відповідає розміщенню водню у октаедричному міжвузлі, а (Vt) у тетраедричному.

3 таблиці видно, що значення спінових магнітних моментів, локалізованих на атомах водню, є в десятки разів більшими за аналогічні, центровані на атомах Ga, In та N. Цікавими є також залежності цих властивостей від концентрації атомів In. Так, значення енергій Фермі зменшуються зі збільшенням атомної частки In в розчині для обох орієнтацій спіна. Густини електронних станів на рівні Фермі зі спіном вгору зростають, тоді як для спінів униз зміна їх не є монотонною. Значення орбітальних магнітних моментів більші за спінові лише на атомах азоту, тоді як на інших атомах - навпаки. Крім того, на інших атомах спінові й орбітальні магнітні моменти антипаралельні, зі значним домінуванням модуля спінового моменту. Значення $\mu_{s}$ та $\mu_{L}$ на $\mathrm{Cr}$ майже нечутливі до зміни концентрації In. Значення $\mu_{s}$ на атомах $\mathrm{H}$, розміщених у міжвузлях (Vo), є другими за величиною після $\mu_{s}$ на атомах Cr. Ці ж величини на атомах $\mathrm{H}$, розміщених у міжвузлях (Vo), приблизно у п'ять разів більші за модулем за аналогічні на атомах $\mathrm{H}$, локалізованих у міжвузлях $(\mathrm{Vt})$. Цікаво, що $\mu_{s}$ на міжвузлях (Vt), навпаки, більші за $\mu_{s}$ на міжвузлях (Vo) також приблизно у п'ять разів. Значення ж орбітальних магнітних моментів $\mu_{L}$ на міжвузлях (Vo) й $(\mathrm{Vt})$ є величинами одного порядку. Зауважуємо, що навіть незначна відмінність між даними першого й другого рядків таблиці, тобто між енергіями Фермі для протилежних орієнтацій спіна, свідчить про існування у кристалі відмінного від нуля магнітного моменту. Аналізуючи дані третього й четвертого рядків таблиці зауважуємо, що значна відмінність числових значень густин електронних станів з протилежними спінами є надійною ознакою існування у кристалі досить великого магнітного моменту.

Т а б л и ц я. Електронні та магнітні властивості твердих розчинів з домішкою водню $(0,1 \%)$, локалізованою в октаедричному (Vo) або у тетраедричному (Vt) міжвузлях. Тут $\varepsilon_{F}-$ енергія Фермі (eB), ир означає спін вгору, $\mathrm{dn}$ - спін униз, $n\left(\varepsilon_{\mathrm{F}}\right)$ - густина електронних станів на рівні Фермі (1/eB/cell/spin), а $\mu_{s}-$ спіновий, $\mu_{L}$ - орбітальний магнітний момент $\left(\mu_{B}\right)$

\begin{tabular}{|c|c|c|c|c|c|c|}
\hline & Jo & $A, \mathrm{Vt}$ & $B, \mathrm{Vo}_{\mathrm{O}}$ & $B, \mathrm{Vt}$ & , Vo & C, \\
\hline & 3 & 1 & 18 & 34 & 11 & \\
\hline & & & & 120 & 118 & 11.06959 \\
\hline & & & & & & J1 \\
\hline & 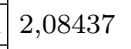 & & & 4, & & 08838 \\
\hline & 0262 & & 0,0 & 0,0 & & 0,00265 \\
\hline & 00008 & $-0,00008$ & $-0,0001$ & $-0,0001$ & -0 , & 000 \\
\hline & 29948 & 2,28828 & 2,28881 & 2,28095 & 2,4 & 2, \\
\hline & 55957 & -0, & $-0,5862$ & $-0,5858$ & -0 & $-0,55473$ \\
\hline & 00195 & 0,0 & 0,00 & 0,0 & 0,0 & 13 \\
\hline & 00026 & -0 & -0 & $-0,0002$ & 0,00009 & 0,00009 \\
\hline & 00147 & 02 & -0, & $-0,0$ & 0171 & $-0,00212$ \\
\hline & 0229 & & 0,0 & & & 84 \\
\hline Vo & 0108 & 0,00105 & 0,001 & 0,00099 & 0,00097 & 0,00096 \\
\hline$L$ on Vo & 00015 & -0 & $-0,0$ & -0, & -0 & 0015 \\
\hline & 0,29271 & -0 , & 0,2 & & & $-0,070$ \\
\hline & $-0,00045$ & $-0,0001$ & $-0,00044$ & $-0,00007$ & $-0,00045$ & $-0,00006$ \\
\hline & 0,00589 & 0,00575 & 0,00488 & 0,00483 & 0,00436 & 0,00431 \\
\hline on $\mathrm{Vt}$ & $-0,00009$ & $-0,0000$ & 0.0000 & -0.00 & -0.0000 & $-0,00006$ \\
\hline
\end{tabular}


$\mathrm{n}(\mathrm{E}), 1 / \mathrm{eV} / \mathrm{cell} / \mathrm{spin}$

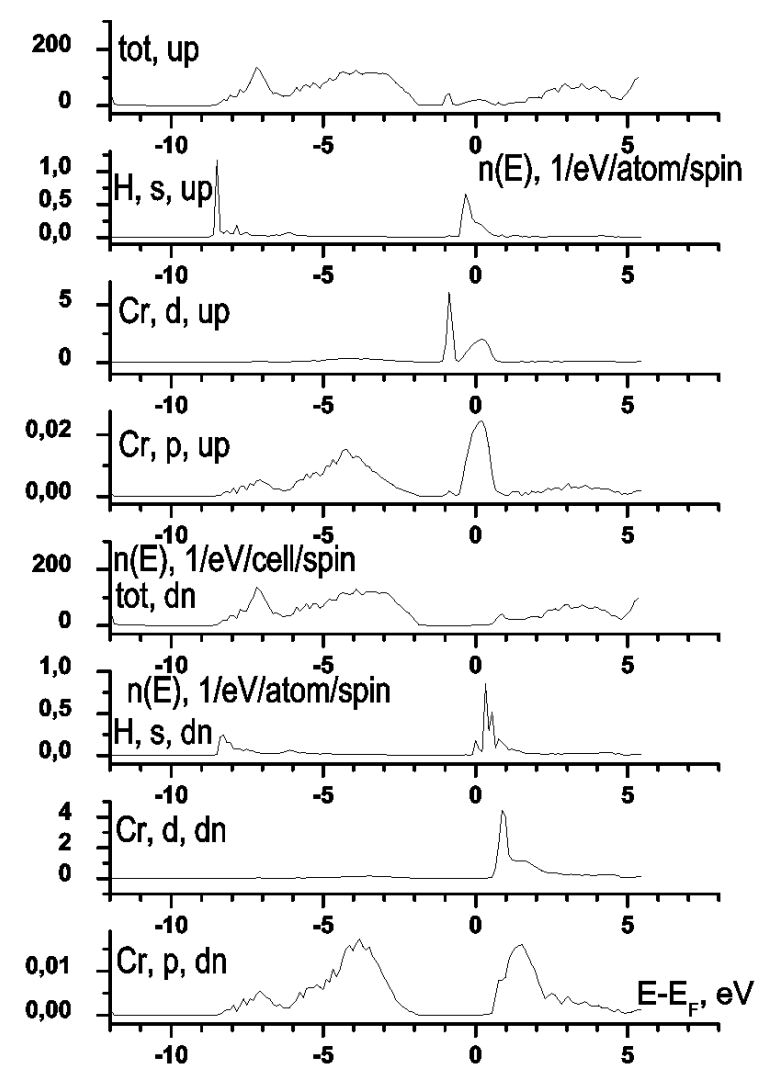

Рис. 1. Парціальні й повні електронні DOS у твердому розчині $\mathrm{Ga}_{0,72} \mathrm{Cr}_{0,03} \operatorname{In}_{0,25} \mathrm{~N}, 3$ домішкою $\mathrm{H}$ (0,1\%), локалізованою у міжвузлі (Vo)

Перейдімо до аналізу графіків густин електронних станів. На рис. 1-6 зображено парціальні й повні густини електронних станів твердих розчинів $\mathrm{Ga}_{1-x-y} \operatorname{In}_{x} \mathrm{Cr}_{y} \mathrm{~N}$ з домішкою $\mathrm{H}$ (0,1\%), локалізованою у міжвузлях (Vo) або (Vt). На графіках зображені парціальні $p$ - і $d$-стани Сr та $s$-стани Н як найбільші за величиною, що підтверджується даними таблиці стосовно значень магнітних моментів на атомах твердих розчинів.

На рис. 1 наведено парціальні і повні густини електронних станів у твердому розчині GaInN $з$ домішкою заміщення Cr. Тут домішка локалізована у міжвузлі (Vo). Перші чотири криві відповідають орієнтації спіна униз. Перші три криві знизу показують, що у забороненій зоні виникають незаселені вузькі зони $p$ - і $d$-симетрії, зумовлені $\mathrm{Cr}$, а також незаселені $s$-стани Н. Четверта крива є повною (tot) DOS. Наступні чотири криві відповідають орієнтації спіна вгору. П'ята й шоста криві показують наявність у забороненій зоні вузьких частково заселених зон $p$ - і $d$-симетрії

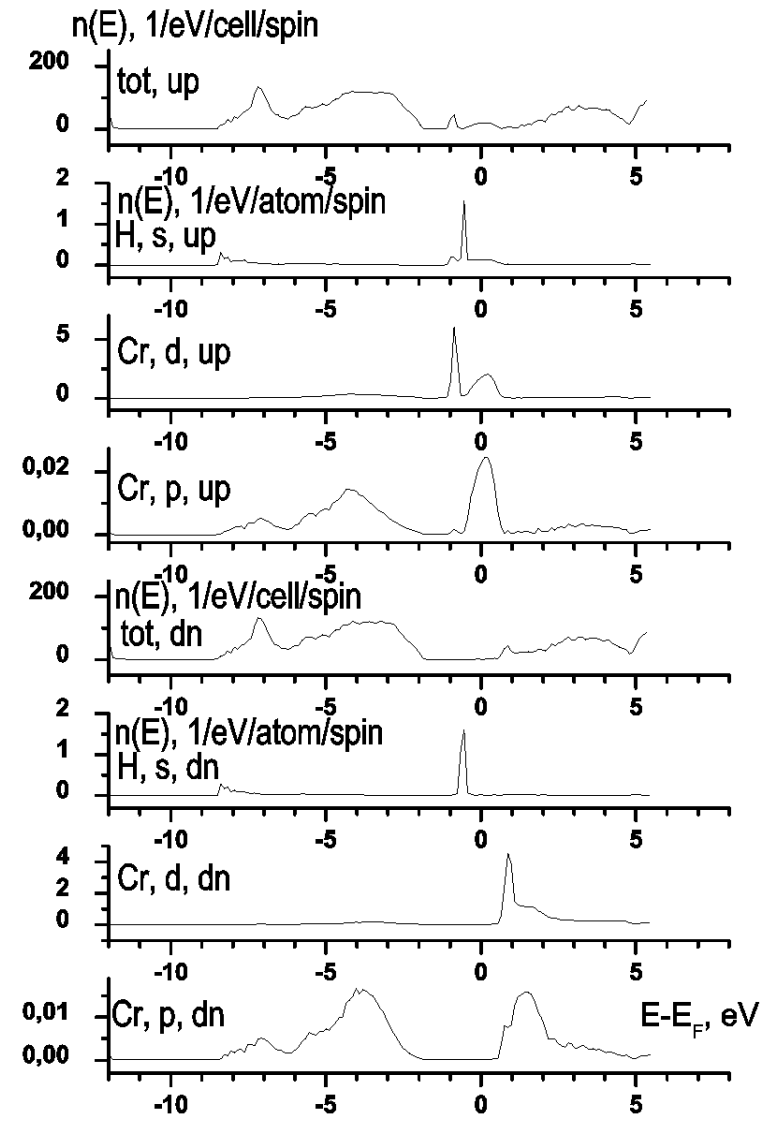

Рис. 2. Те саме, що й на рис. 1,3 домішкою $\mathrm{H}(0,1 \%)$, локалізованою у міжвузлі (Vt)

зі спіном вгору, зумовлених присутністю домішки Cr. Зауважуємо, що і заселені електронами і вільні зони є вузькими та сильно гібридизованими. Сьома крива зображує частково заселені $s$-стани Н. Восьма крива відображає повну DOS. Очевидно, що повні DOS у забороненій зоні зазнали змін, зумовлених впливом домішок $\mathrm{Cr}$ та H. Однак структура зміненої DOS легко пояснюється за допомогою парціальних DOS.

На рис. 2 зображено густини станів у кристалі GaI$\mathrm{nN}$ з домішками заміщення $\mathrm{Cr}$ та Н. Тут домішка локалізована у міжвузлі (Vo). Порівнюючи парціальні DOS на рис. 1 і 2, зумовлені домішками $\mathrm{Cr}$, бачимо, що вони є практично однаковими. Однак детальне порівняння кривих, відповідних парціальним DOS на атомах Н, вказуе на значну відмінність. Так, у разі локалізації водню у міжвузлі (Vo) зумовлена ним вузька зона зі спіном униз незаселена, тоді як за локалізаціі його у міжвузлі $(\mathrm{Vt})$ вона заселена. У разі локалізації водню у міжвузлі (Vo) зумовлена ним вузька зона зі спіном вгору частково заселена, тоді як за локалізації його у міжвузлі (Vt) вона заселе- 
$\mathrm{n}(\mathrm{E}), 1 / \mathrm{eV} / \mathrm{cell} / \mathrm{spin}$

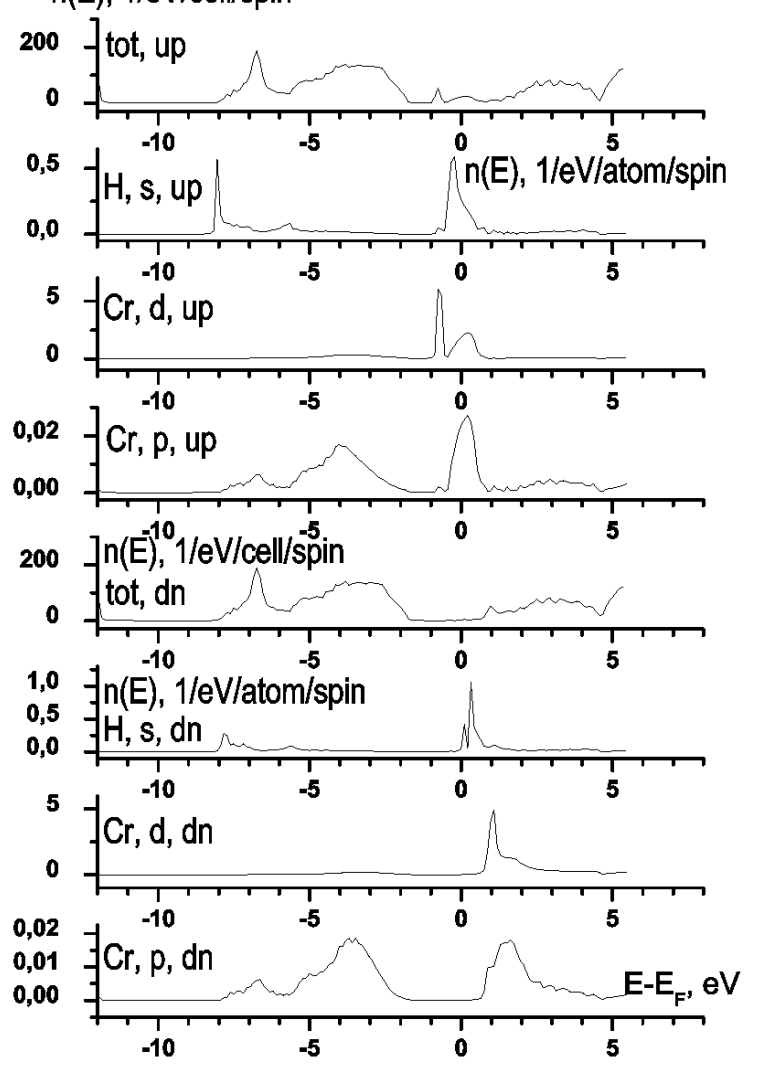

Рис. 3. Парціальні й повні електронні DOS у твердому розчині $\mathrm{Ga}_{0,47} \mathrm{Cr}_{0,03} \operatorname{In}_{0,5} \mathrm{~N}, 3$ домішкою $\mathrm{H}(0,1 \%)$, локалізованою у міжвузлі (Vo)

на. За допомогою парціальних DOS на атомах H, зображених на рис. 1, 2, можна якісно визначити, що більше значення магнітного моменту буде на атомі водню, локалізованому у міжвузлі (Vo). Справді, значення магнітного моменту пропорційне різниці площ під кривими, відповідними спінам вгору й униз. Ця різниця більша для рис. 1 і мала для рис. 2, а відповідні моменти наведені у таблиці і дорівнюють $0,29 \mu_{B}$ та $-0,06 \mu_{B}$ відповідно.

На рис. 3, 4 подано парціальні та повні DOS у твердому розчині $\mathrm{GaInN}$ з домішкою заміщення $\mathrm{Cr}$, у якому концентрація In дорівнює $50 \%$, а домішка водню локалізована у міжвузлі (Vo) або (Vt) відповідно. 3 рис. 3 видно, що парціальні DOS на атомах $\mathrm{Cr}$ та Н зі спіном униз відповідають незаселеним зонам, тоді як зі спіном угору - частково заселеним. На рис. 4 показано, що парціальні DOS на атомах Н зі спіном униз і вгору відповідають заселеним зонам $s$-симетрії.

Криві, зображені на рис. 5, 6, є парціальними й повними DOS твердих розчинів зі вмістом In $75 \%$. На

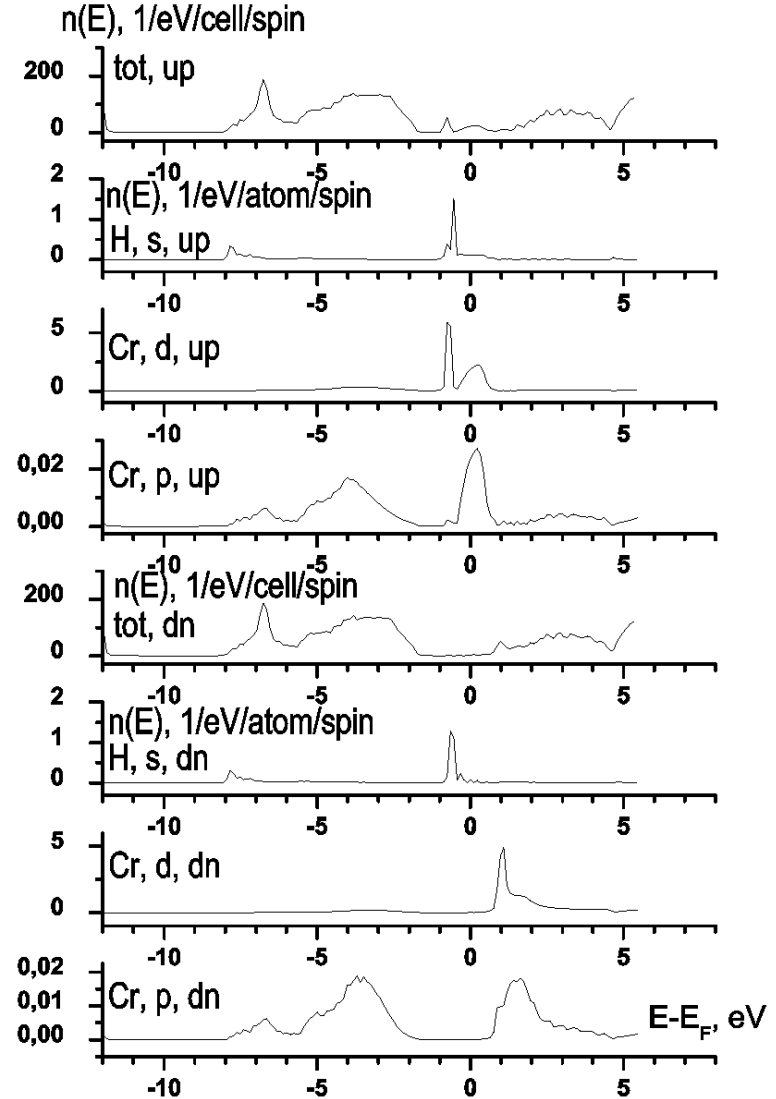

Рис. 4. Те саме, що й на рис. 3 , з домішкою $\mathrm{H}(0,1 \%)$, локалізованою у міжвузлі $(\mathrm{Vt})$

рис. 5 парціальні DOS на атомах $\mathrm{Cr}$ та $\mathrm{H}$ зі спіном униз відповідають незаселеним вузьким зонам, а зі спіном угору - частково заселеним. Однак на рис. 6 парціальні DOS на атомах Н відповідають заселеній вузькій зоні $s$-симетрії зі спіном униз, а для спіна вгору тепер маємо частково заселену зону з $s$-станів, тоді як відповідні зони, індуковані воднем, див. рис. 2, 4, є заселеними.

Отримані нами результати якісно узгоджуються 3 апріорним розрахунком густин електронних станів, отриманих за допомогою методу зберігаючих норму атомних псевдопотенціалів у кристалі GaN 3 домішкою Mn [12]. У цьому методі наближення МТ потенціалу не використовується. 3 роботи [12] бачимо, що $3 d$-стани марганцю знаходяться на рівні Фермі, а ширина домішкової зони приблизно дорівнює 1,5 eВ. У роботі $[13,14]$ також знаходимо якісне зіставлення результатів, отриманих для $\mathrm{GaN}$ з домішкою Mn. У них застосовані різні апріорні псевдопотенціали і також отримані $3 d$-стани марганцю на рівні Фермi. 


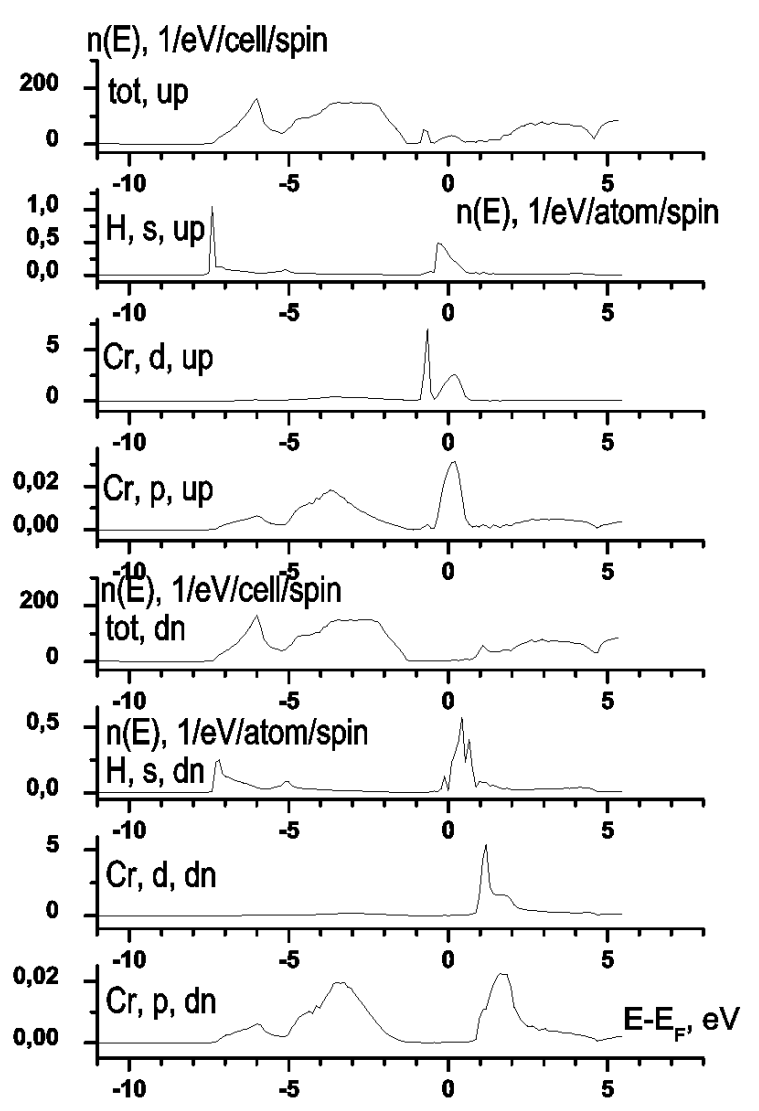

Pис. 5. Парціальні й повні електронні DOS у твердому розчині $\mathrm{Ga}_{0,22} \mathrm{Cr}_{0,03} \mathrm{In}_{0,75} \mathrm{~N}$, 3 домішкою $\mathrm{H}(0,1 \%)$, локалізованою у міжвузлі (Vo)

Автори експериментальної роботи [15] виявили феромагнетизм у кристалі GaN з домішкою Mn i запропонували критерій, згідно з яким цей стан виникає за умови, що рівень Фермі знаходиться всередині зони, утвореної станами Mn, що містяться у забороненій зоні матриці. В експериментальній роботі [16] виявлено феромагнетизм за кімнатних температур у кристалі $\mathrm{GaN}$ з домішкою $\mathrm{Cr}$ і зроблено висновок про те, що $\mathrm{GaN}: \mathrm{Cr} €$ одним із кандидатів для застосування у спіновій електроніці.

3 іншого боку, наявні експериментальні дані часто суперечливі. Одні джерела стверджують, що феромагнетизм за високих $T_{c}$ досяжний у системі $\mathrm{GaMnN}$ [17]. В інших йдеться про антиферомагнетизм в GaMnN [18] або парамагнетизм [19]. Природа магнетизму в цій системі також поки що $е$ предметом дискусії [20]. Деякі дослідники припускають, що спостережуваний феромагнітний стан може зумовлюватись вторинними фазами, і що GaMnN є спіновим склом [21]. Інші стверджують, що ні-

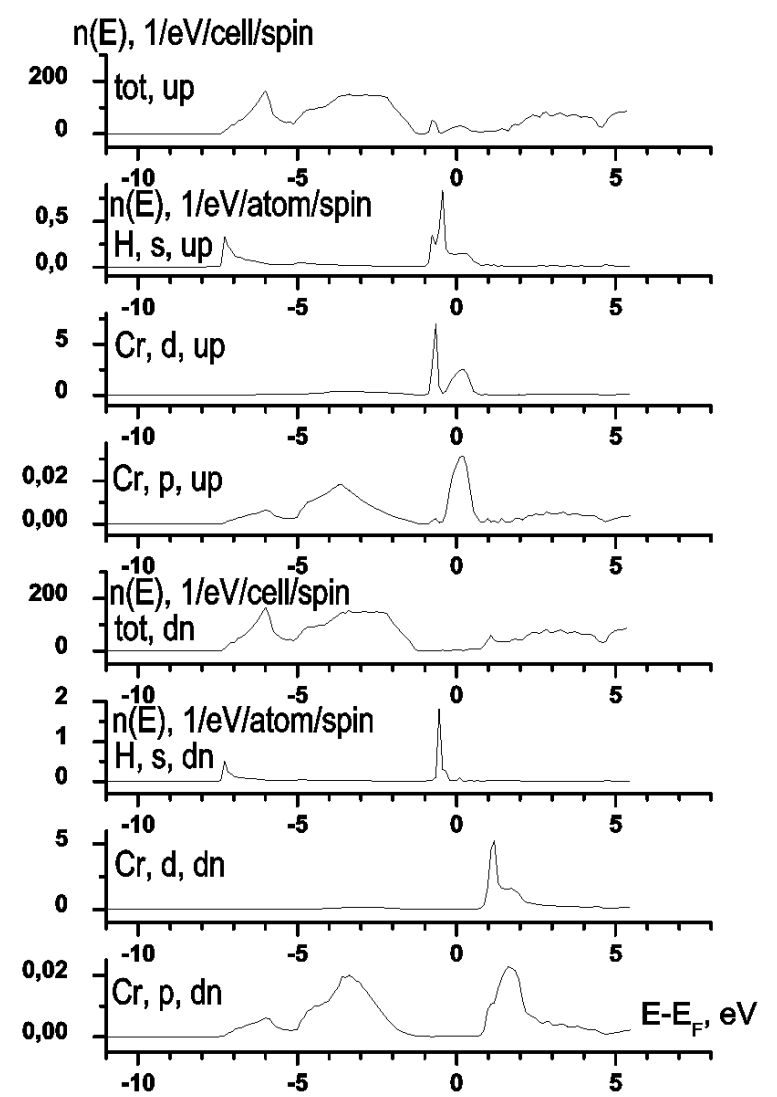

Рис. 6. Те саме, що й на рис. 5, з домішкою $\mathrm{H}(0,1 \%)$, локалізованою у міжвузлі (Vt)

якої вторинної фази не спостерігається в монокристалових зразках $\mathrm{GaMnN}$ з феромагнітним порядком [22].

Експериментальні й теоретичні результати для систем GaInN з домішками перехідних $3 d$-елементів нам невідомі.

\section{4. Висновки}

Розраховані парціальні й повні DOS твердих розчинів $\mathrm{GaInN}$ з домішкою заміщення $\mathrm{Cr}(3 \%)$ та атомами водню $(0,1 \%)$, локалізованими у міжвузлях (Vo) або $(\mathrm{Vt})$. Виявлено значний вплив домішки водню на значення густин електронних станів на рівні Фермі для обох орієнтацій спіна (див. таблицю). Розраховані спіновий та орбітальний магнітні моменти на атомах та міжвузлях. Орбітальний момент отриманий завдяки врахуванню спін-орбітальної взаємодії. Найбільших значень набувають спінові та орбітальні моменти на атомах $\mathrm{Cr}$, а також спінові - на атомах Н. Значення спінових та орбітальних моментів на всіх атомах 
твердого розчину слабко залежать від концентрації In. Справді, In та Ga ізовалентні. Однак енергії Фермі помітно знижуються зі збільшенням вмісту In, а густини електронних станів зі спінами вгору суттєво зростають.

3 рис. 1-6 робимо висновок про докорінну зміну електронної структури, спричинену домішками Cr та Н. У забороненій зоні завдяки останнім з'являються $s$-, $p$ - й $d$-стани водню й хрому.

У якому міжвузлі розміщення атомів водню є більш імовірним? Повні енергії зв'язку твердих розчинів, за локалізації атомів Н у міжвузлях (Vo) або (Vt), близькі за величиною для розглянутих концентрацій In. Так, за вмісту In $25 \%$ відповідні енергії зв'язку дорівнюють $(R y):-5904,8713$ та $-5904,8711$, за вмісту In 50\%: $-7872,4489$ та $-7872,4490$, за вмісту In 75\%: -9840,1012 та -9840,1010, відповідно. Тобто, найбільша різниця повних енергій зв'язку дорівнює $0,0002 R y$ або 0,0027 еВ. Отже, локалізація атомів водню у міжвузлях $(\mathrm{Vo})$ або $(\mathrm{Vt})$ майже рівноймовірна.

3 рис. 1-6 можна зробити висновок про те, що наближення ефективної маси у вузьких зонах, індукованих домішками хрому й водню, незастосовне.

Висловлюємо подяку професорові Х. Акаї (H. Akai, Osaka University) за надання найновішої версії програми AkaiKKR-LSDA.

1. K.S. Burch, D.D. Awschalom, and D.N. Basov, J. Magn. Magn. Mater. 320, 3207 (2008).

2. H. Morkoc, Handbook of Nitride Semiconductors and Devices, Vol. 2 (Wiley, Weinheim, 2008).

3. C.G. Van de Walle and J. Neugebauer, J. Appl. Phys. 95, 3851 (2004).

4. N. Newman, S.Y. Wu, H.X. Liu, J. Medvedeva, L. Gu, R.K. Singh, Z.G. Yu, I.L. Krainsky, S. Krishnamurthy, D.J. Smith, A.J. Freeman, and M. van Schilfgaarde, Phys. Status Solidi A 203, 2729 (2006).

5. C.G. Van de Walle and J. Neugebauer, Phys. Status Solidi B 248, 19 (2011).

6. H. Akai, Phys. Rev. Lett. 81, 3002 (1998).

7. N.H. Long and H. Akai, J. Phys. Condens.Matter 19, 365232 (2007).

8. V.L. Moruzzi, J.F. Janak, and A.R. Williams, Calculated Electronic Properties of Metals (Pergamon, New York, 1978).

9. J.M. MacLaren, D.P. Glougherty, M.E. McHenry, and M.M. Donovan, Comp. Phys. Commun. 66, 383 (1991).
10. H.J. Monkhorst and J.D. Pack, Phys. Rev. B 13, 5188 (1976).

11. H. Ebert, A Spin Polarized Relativistic KorringaKohn-Rostoker (SPR-KKR) Code for Calculating Solid State Properties (Universität München, München, 2010); http://olymp.cup.uni-muenchen.de/ak/ebert/SPRKKR.

12. L. Kronik, M. Jain, and J.R. Chelikowsky, Phys. Rev. B 66, 041203(R) (2002).

13. B. Sanyal, O. Bengone, and S. Mirbt, Phys. Rev. B 68, 205210 (2003).

14. P. Mahadevan and A. Zunger, Appl. Phys. Lett. 85, 2860 (2004).

15. E.A. Berkman, M.J. Reed, F..E. Arkun, N.A. El-Masry, J.M. Zavada, M.O. Luen, M.L. Reed, and S.M. Bedair, Mater. Res. Soc. Symp. Proc. 834, J7.3.1 (2005).

16. J.H. Chun, and D.E. Kim, Phys. Status Solidi A 208, 691 (2011).

17. S.-H. Wei and G.M. Dalpian, SPIE Proc. 6894, 68940L (2008).

18. Y. Shon, Y.H. Kwon, Sh.U. Yuldashev, J.H. Lim, C.S. Park, D.J. Fu, H.J. Kim, T.W. Kang, and X.J. Fan, Appl. Phys. Lett. 81, 1845 (2002).

19. K. Ando, Appl. Phys. Lett. 82, 100 (2003).

20. Q. Wang, Q. Sun, P. Jena, and Y. Kawazoe, Phys. Rev. Lett. 93, 155501 (2004).

21. S. Dhar, O. Brandt, and A. Tampert, Appl. Phys. Lett. 82, 2077 (2003).

22. S.J. Pearton, C.R. Abernathy, G.T. Thaler, R.M. Frazieer, D.P. Norton, F. Ren, Y.D. Park, J.M. Zavada, I.A. Buyanova, W.M. Chen, and A.F. Hebard, J. Phys. Condens. Matter 16, R209 (2004).

Одержано 05.07.11

\section{ЭЛЕКТРОННАЯ СТРУКТУРА ТВЕРДЫХ РАСТВОРОВ GaInN C ПРИМЕСЬЮ ХРОМА И ВОДОРОДА}

\section{C.B. Сиротюк, В.М. Швед}

$\mathrm{P}$ е $з$ ю м е

Электронные и магнитные свойства твердых растворов GaI$\mathrm{nN}$ с примесью хрома и водорода были рассчитаны методом функции Грина. Полученные парциальные и полные спинполяризованные плотности электронных состояний указывают на коренную перестройку электронной структуры кристалла, вызванное атомами замещения $\mathrm{Cr}$ и межузловыми примесными атомами водорода. Изменения связаны с появлением в запрещенной зоне узких гибридизованных зон $s$-, $p$ - и $d$ симметрии, отсутствующих в твердых растворах GaInN. 
ELECTRONIC STRUCTURE OF CHROMIUMAND HYDROGEN-DOPED GaInN SOLID SOLUTIONS

\section{S.V. Syrotyuk, V.M. Shved}

Lviv Polytechnic National University, Faculty of Semiconductor Electronics (12, S. Bandera Str., Lviv 79000, Ukraine; e-mail: svsnpe@yahoo.com)

$\mathrm{S} \mathrm{u} \mathrm{m} \mathrm{m} \mathrm{a} \mathrm{r} \mathrm{y}$

Electronic and magnetic properties of GaInN solid solutions doped with chromium and hydrogen impurities have been calculated with the use of the Green's function method. The obtained partial and total spin-polarized densities of states (DOS) point to a fundamental restructuring of the electronic structure in the crystals, which is induced by $\mathrm{Cr}$ substitutional and hydrogen interstitial impurity atoms. The changes are associated with the appearance of narrow hybridized states with $s_{-}, p-$, and $d$-symmetries in the energy gap, which are absent from GaInN solid solutions. 